\title{
Frederica Potter's Ritual and Regeneration in A. S. Byatt's The Virgin in the Garden
}

\author{
Yifan Lee
}

\begin{abstract}
This paper aims at exploring A. S. Byatt's The Virgin in the Garden (1978), the first volume of "Frederica Quartet," with close examination of the mythical elements in the novel and psychoanalytical views on the formative process of Frederica's rite of passage. This paper attempts to apply mythical and psychoanalytical approaches in analyzing the motives and mental influences of Frederica's time on her. The result shows that, in the novel, the rite of passage is closely connected with the ritual and regeneration of the nation on the outside and the collection of personal identity (as represented by the condition of "ego" in psychoanalysis) on the inside.
\end{abstract}

Index Terms-A. S. Byatt (1936-), Eliade, Mircea (1907-86), Lacan, Jacques (1901-81), The Virgin in the Garden (1978).

\section{INTRODUCTION}

A. S. Byatt's The Virgin in the Garden (1978) depicts the lives of a group of characters in North Yorkshire, England, during the 1950s. As the first volume of the "Frederica Quartet," The Virgin mainly portrays the middle-class intellectual life of Frederica Potter, who dreams of becoming an actress. As the story progresses, she undertakes her "initiation," which amounts to a personal and collective regeneration. Like a mirror, the theater allows Frederica to see herself as a reflection, which, psychoanalytically speaking, is her ideal ego as the young Queen Elizabeth I in Astraea. The image behind the theatric mirror is a body composed of narratives: in Frederica's case, her reading constitutes her knowledge of literature, her experiences in acting, and her idea of sex and love that connects her to the adult's world. In other words, Frederica cannot fully inhabit her body and ego until she has had more experiences in courtship and sex, which is equivalent to the initiation rite of modern people. By means of such experience, Frederica can literally "put herself together" in all possible ways. In The Virgin, Frederica and other characters struggle through their rites of passage, which involves ritual, mythical, and psychoanalytical explorations of life against a background of mythical collective regeneration. This is, of course, a reflection of Byatt's Weltanschauung (world view). Thus, the novel provides a glimpse of Byatt's particular perspective of her native North Yorkshire community in the 1950s.

Manuscript received December 10, 2015; received March 2, 2016. This paper is a revision of the chapter 1 "ritual and regeneration of Frederica Potter in A. S. Byatt's The Virgin in the Garden," of my $\mathrm{PhD}$ dissertation that is supposed to be a partial fulfillment of the completion of my $\mathrm{PhD}$ degree, planned to be obtain in June, 2016.

Yifan Lee is with the Foreign Languages and Literature Department, National Cheng Kung University, Tainan, Taiwan R.O.C. (e-mail: Yifanlee32@gmail.com).

\section{THE DAWNING OF A NEW ORDER}

The Virgin begins with Queen Elizabeth II's ascent to the throne, which symbolizes the beginning of a new era. As part of the celebration of the coronation, Alexander Wedderburn's verse drama Astraea brings recalls people's memories of the era of Elizabeth I, which is cited as the "Golden Age" of the history of England. Through the novel's comparison of the theatrical world, readers can see how Byatt uses the theatre as a metaphor, illustrating Frederica's life by comparing it to the theatrical representation of Elizabeth I, whose mythical and psychoanalytical personality play a significant role in the novel. Frederica's initiation consists of experiencing the ego-formation process in carnivals of narratives, in which chaos and order, virginity and fecundity are faces of the same coin.

In The Virgin, the coronation serves as the national fairytale of regeneration. The regeneration theme lies in many metaphors, especially the repeated appearance of the phrase "Redit et Virgo", even appearing as the title of a chapter. "Redit et Virgo, iam Saturna regna" (the Virgin returned, and the honored order of Saturn come again) is a quote from Virgil's Eclogue IV used in Alexander's Astraea. It is quoted several times to describe the jubilant gatherings of the Elizabethan era. Because of its multiple connotations, the "return of the Virgin" becomes a repeated theme in The Virgin. It alludes to the glorious reign of Elizabeth I and the coronation of Elizabeth II as a "true Renaissance" [1] (299). The phrase also ironically alludes to Frederica's homecoming after defloration.

Queen Elizabeth's coronation (2 June, 1953) was the first coronation of an English Monarch to be broadcast on television. This new way of communication brought new significance to an established event. The camera began to create holy moments, in which past and present, death and rebirth, were all remembered in the rituals of regeneration. Indeed, at that time, the Queen became the center around which a whole nation was regenerated and empowered. In The Virgin, it is commented that the whole English society was built on the conception of mystical renewal, which "extends itself beyond and through the life of the individual to the life of the family and of the tribe and of the nation" [1] (184). The coronation of the young Queen, Elizabeth II, was a "victory" of spring's annual message, which transcended the death brought about by the winter with the power of new life [1] (185). At the beginning of Part II of The Virgin, Byatt inserts an excerpt of a newspaper article dated April 6, 1953, between the chapters. The excerpt from The Times, titled "Dawn of the Year," discussed the meaning of Easter, from its origin as the "Old New Year's Day" [1] (183) to its 
significance as the beginning of a new cycle of natural regeneration. For local English people, Easter means "the sudden discovery that the annual miracle of the spring has come upon him unawares." It is the time when the English people find in the country "all signs of rebirth" [1] (183). Thus, Easter symbolizes the beginning of a new era, an annual renewal of the world. In fact, not only the rural areas, but the whole nation undergoes a change during Easter. Alexander's Astraea, for example, considers it "the nation's feast of mystical renewal" [1] (185). For Frederica, it is a ritual of passage and initiation. The performance of the play is a threshold through which Frederica experiences self-satisfaction and disillusion. In the next chapter, "Easter," the narrator of The Virgin evaluates the English Easter by comparing it with a "cleansing ritual slaughter" that can renew natural energy [1] (189). The comparison between natural cycles and ritual killing is both beautiful and disturbing. It may also allude to Lucas' sacrificial ceremony at the end of The Virgin.

The narrator's concept of Easter as a ceremony of natural renewal can be interpreted in light of the concept of annual regeneration rites as explained by Romanian historian and philosopher Mircea Eliade (1907-1986). According to Eliade, the coronation of the monarch plays a significant role as the center of regeneration. By means of the ceremony, universal renewal is thus connected with actual persons and events, while the king (or queen) becomes "responsible for the stability, the fecundity, and the prosperity of the entire Cosmos." [2] (40-41). Therefore, Queen Elizabeth II's coronation gives the hope of renewal of the nation following WWII and the Queen herself is considered the central symbol of national regeneration.

Since the fate of the nation is connected with the monarch, it is also possible that the character of the monarch influences that of the nation. In the chapter "Coronation," there is a lay psychological examination of the Queen's mental condition and background from childhood that takes place during the recounting of the coronation. The reporter Richard Dimbleby comments that Elizabeth II's character is "well known to be the product of a happy childhood," wherein she led a sound family life, full of love [1] (300). The character of Elizabeth I, by contrast, is the product of a dysfunctional family and unhappy early life. "This grim childhood," comments Dimbleby, fostered the development of Elizabeth I's "wiles and cunning" [1] (300-301). While these comments irritated Alexander, who thought they lacked heartiness and good sense of spoken language [1] (302), not everyone was displeased by the rather coarse comparison and contrast of the two queens. Indeed, Edmund Wilkie found these remarks interesting, enthusiastically quoting psychoanalyst Donald Winnicott (1896-1971) to build his case that Dimbleby's comments were accurate. According to Wilkie's report, Winnicott claims that rulers are "surrogate parents" of the people they rule. However, Wilkie's remarks elicited Bill's discontent. This exchange makes it clear that. Dimbleby's remarks and Winnicott's theory brought a psychoanalytical depth to the discussion of the meaning of a new monarch in The Virgin. The national myth of the monarch is challenged by the rising trend of psychoanalysis and science. In addition, Dimbleby and Wilkie point out an important theme in The
Virgin, which is the suggested relationship between Queen Elizabeth I and II, between Renaissance and present-day England, and the possible connection between modern English people and national history and myth.

The sovereign's inauguration implies the creation and return to order in the universe, epitomized by the ripening of crops, which is symbolized by the virgin goddess with a sheaf in her hand [3]. For example, one of the passages depict Queen Elizabeth I as under the sign of Virgo, as Virgo-Astraea, and a goddess of Justice. Corresponding to that concept, in The Virgin, the Queen's virginity, is “quite closely related to much nastier savage harvest-deities - Cybele, Diana of Ephesus, Astarte" [1] (170). These goddesses are deities of fertility worshiped by ancient agricultural peoples, such that many of them are synonymous with Mother-Earth [4]. Therefore, in the context of The Virgin, Queen Elizabeth I is endowed the character of mythical Mother-Earth, who is suggested as androgynous with by having a cornucopia between her legs [1] (169). In fact, Elizabeth I being characterized in this way is a crucial component of the mythical theme of The Virgin.

The Ovidian myth and the condition of virginity relates Queen Elizabeth I and Frederica. Thus, the coronation of Elizabeth II leads to "a revival of the Elizabethan era and of the renaissance of Ovidian influence" [5] (268). The Ovidian metaphors, penetrated by psychoanalytic viewpoints, paves the way to initiation for Frederica, who says she does not does not believe in Christianity or any other religion. Yet, however she defines her belief, according to Eliade, Frederica may still have some kind of "mythical attitude" that can be discerned in her daily life, as well as in her "unconscious psychic activity", such as her dreams, fantasies, and so on [6] (37). Furthermore, in The Virgin, Frederica strives to transcend her "local, provincial history" to recover some "Great Time"; i.e., the mythical time of Elizabeth I [6] (33). In light of this, Lucas' "baptism" and self-mutilation at the end of the novel could be regarded as a suggestion of sacrifice to Mother-Earth, and, as a result, implicate the character of Lucas as a representations of regeneration in the novel.

Looking back, Frederica's 1950s was a time of teenage turbulence. However, it was in this context that she semi-consciously went through her initiatory rite. The narrator concludes that Frederica, could only look back at her "pastel" teenage years with an "almost-adult knowledge that everything was a new beginning" when she was eventually old enough [1] (299). Multiple significances and qualities exist within the two queens, who suggest two choices for Frederica's life direction. Queen Elizabeth I is a virgin queen born under the sign of Virgo, which symbolizes fertility. However, her fertility comes from her hermaphroditic quality, one which is frequently attributed to witches or pagan gods. Elizabeth II, on the other hand, is a married woman with children. She, sharing the same name with the first queen of England, is opposite to Elizabeth I in almost every aspect. By playing Elizabeth I within the reign of Elizabeth II, Frederica has found herself connected to Elizabeth I. Acting in Astraea thus becomes a chance to catch the movement of regeneration in the epoch. It is also the experience that connects her to the mythical Queen, a mirror image and a parody. Without being aware of this, Frederica begins her journey of initiation. The 
first step of her initiation is to reform her ego in the chaotic stages of "Saturnalia."

\section{SATURNALIA AND EGO FORMING}

In The Virgin, the chapters titled "Saturnalia" and "St. Bartholomew" depict several incidents wherein Frederica meets the ugly reality of the adult world. Saturnalia is an ancient Roman festival, and is a time of merry-making and social liberation. The festival symbolizes retrogression of the cosmos into chaos before a new order is established once more. Psychoanalysts have also noted Saturnalia and dedicated much consideration to the phenomenon. Freud, on commenting on the formation of the ego, wrote that Saturnalia and modern carnivals, which usually "end in debaucheries" and a transgression of rules, are actually the "festival" of the ego ideal, which require "all the limitations" that is acquiescent. This is the process through which the ego ideal feels "satisfied with itself", resulting in it becoming an ego which is aware of its limits [7] (105). According to Freud, "a periodical infringement of the prohibition" set by the law is necessary for the ego ideal to explore and recompose itself [7] (105). Saturnalia serves as such a time of infringement. The temporary suspension of existing order, as symbolized by the ego ideal, becomes a prerequisite, and necessary process of the working of the ego.

Jacques Lacan further explores the question of the formation of ego from ego ideal. The ego, according to Lacan, is a "structure of language" [8] (11), and the mirror stage is a "drama" required by the early development of the ego [9] (78) Mirror Stage is classified as "one of the stages in the development of the child" and refers to both (1) a "decisive turning-point in the mental development of the child," and (2) "an essential libidinal relationship with the body-image." [8] (14). These two functions demonstrate clearly "the passing of the individual to a stage where the earliest formation of the ego can be observed" [8] (14). Generally speaking, ego can be a constitutive platform or plane, like a mirror, wherein the subject sees himself as a complete, autonomous person.

Furthermore, according to Lacan, this "illusion of unity [of the ego], [...] entails a constant danger of siding back again into the chaos from which he started" [8] (15). That is, the formation of ego is a continuing process similar to that of mythical regeneration; it may undergo periodical renewal and restructuring, as expressed in Eliade's theorizing of the natural cycles of primitive people. In The Virgin, such a natural cycle is mainly expressed in the meaning of Easter and the mythical regeneration of the characters, especially Frederica. However, such changes in the environment may also echo the inner world of the heroine.

Lacan uses the illustration of vase and flower through a concave mirror to demonstrate the structure of the ego through the gaze of a subject [10] $(565,570)$. He comments that one sees his ideal ego like he sees the virtual image of the flower in a vase, while in reality the flower and vase are separated. Lacan demonstrates this in the Fig. 1.

This suggests the possibility of one "seeing" her ideal ego, which is composed of fragmental images. The seeing subject, feeling himself to be in the space "behind the mirror," relates himself with the complete image, even though this relation is an imaginary one. The visual relation process is the way in which the ideal ego is identified, and constitutes an ideal image of "I" for the child or teenager who quests for self-identity. This process, according to Lacan, drags the subject into the field where "he hypostasizes himself in the ego-ideal [10] (569). This is the mechanism by which it is possible for one to see their ideal self during the search for identity. In The Virgin, as the first step towards her initiation, Frederica's ego ideal is penetrated by the narrative of theater. More specifically, she identifies images of herself in the process of Astraea's production. The theater is a mirror, and the roles are dressed to become characters like flowers in vases. Frederica, in the young queen's dress, begins to explore herself by means of imitating the character of Elizabeth I and repeating her lines and inner thoughts.

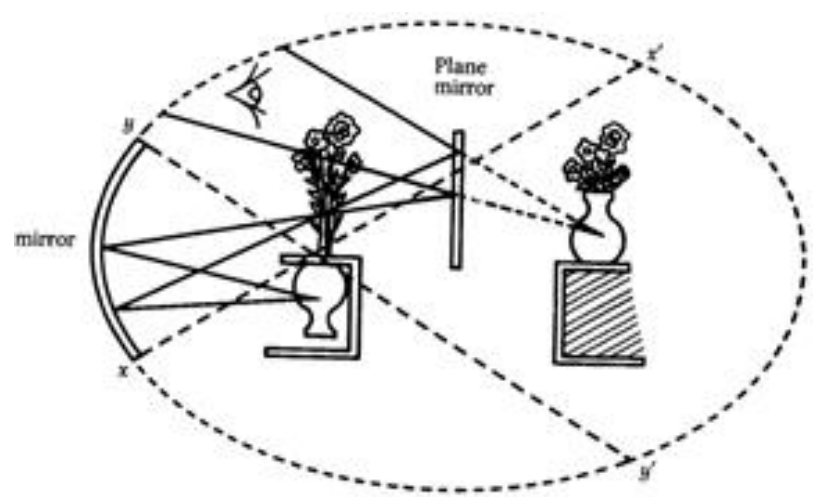

Fig. 1. Lacan, Jacques, Ecrits p.565.

The psychoanalytical theories of ego formulated by both Freud and Lacan have bearing on the formation of Frederica's ego ideal in the mirroring of the theater. Like the mirror, the theater allows Frederica to see herself as a reflection, her ideal ego being the young Queen Elizabeth I. The image behind the mirror is a body composed of narratives: in Frederica's case, her reading constitutes her knowledge of the world, and her experiences constitutes her consciousness. However, according to the theories of Eliade and Freud, she cannot fully grasp her body and ego until she has had more significant experiences, such as courtship and sex, which are the equivalent of an initiation rite for modern people. In "Saturnalia," sex becomes an initiatory passage for Frederica. She needs to prove herself to be a worthy member of society, even though "society" here consists only of a temporary local theatre group. During the processes of auditioning, acting, and flirting, Frederica learns about the possibilities, limits, and feelings associated with desiring something. Hidden boundaries between herself and other people begin to appear in her cognition of herself. These boundaries form her ego, leading her to say to Stephanie, "You know I am not a child. I want ... I want, I want, I want" [1] (445). By means of that, Frederica has literally "put herself together" against all the possible ways things would develop.

"St. Bartholomew" is a chapter about chaos and sacrifice. It is a threshold to initiation for Frederica that can be overcome with sacrifice. Meanwhile, St. Bartholomew, flayed and put back together in mythology, is also a symbol of resurrection. Jenny, one of the actors of Astraea, has warned 
Frederica about self-sacrifice. Jenny's words at Frederica's birthday party illustrate the intellectual married woman's despair. Perhaps under the influence of alcohol, Jenny tells Frederica never to give up what she meant to be for marriage. "[D]on't suppose that the death of the mind can be avoided by a little rushed reading between two lots of nappies and dishes, because it can't" [1] (470). Jenny warns Frederica against sacrificing herself for family from her position as an initiated member of a community. She delineates the danger, as a woman, of losing one's self-esteem and aspiration in marriage. It is imaginable that Jenny has already experienced the deprivation she describes, and wants to warn Frederica against her example. Like Anthea Warburton's accidental pregnancy, Jenny's warning foreshadows Frederica's rough course of initiation and regeneration.

Theories of initiation, ego-formation, and sacrifice point out the importance of achieving renewal through festival chaos, whether it is the law for the nation and society, or the person's mind. In light of the concept of regeneration through chaos, the readers of The Virgin find that Frederica's initiation ordeal mostly documents her pursuit of freedom and adulthood, which involves self-actualization through acting (her goal in the novel) and sexual consummation.

\section{CONCLUSION: THE RETURN}

Throughout The Virgin, the quote from Virgil, "Redit et Virgo, iam Saturna regna." is echoed several times on different occasions, and rendered to have different meanings depending on various situations. In the last chapter of the novel, "Returns," Frederica returns from her accidental escape with Wilkie, to whom Frederica has given her virginity. Instead of returning with the "honored order," Frederica returns to find that everything has changed. These events prepare the stage for yet another drama of Frederica's life. The celebration of a ritual implies the remembering of origin, and personal requests coincide with social celebrations (e.g., the theater,) and national regeneration (the Queen's coronation). All these requests, however, center on certain rites that recall or the original time.

Frederica's rite of regeneration relies on the power of narrative. The stories recounted carry marks or traits related to the formation of the ego and passage of initiation. Also, Frederica's initiatory rite is a journey toward her "divine origin" in the face of life's abundance and lack. Repeating the old rituals is a necessary part of entering the adult stage, as Eliade comments: "The initiatory rites reactualize an origin myth, which relates the adventures, death, and resurrection of a divinity" [11] (175). The Virgin demonstrates the process of compilation of Frederica's ego through invented and experienced narratives. The theory of Eliade connects Queen Elizabeth I to the Mother-Earth and portray her as an androgynous goddess, such that she becomes symbol of fertility as a virgin. In sum, Queen Elizabeth II's coronation and Queen Elizabeth I's mythical virginity prompt Frederica not only to consider but also earn her place in the world. This is what an "ego-forming process" really means in The Virgin.

\section{REFERENCES}

[1] A. S. Byatt, The Virgin in the Garden, New York: Vintage, 1992.

[2] M. Eliade, The Myth and Reality, W. R. Trask, Trans. Long Grove, IL: Waveland P, 1998

[3] M. Eliade, The Myth of the Eternal Return: Cosmos and History, W. R. Trask, Trans. Princeton UP, 2005.

[4] M. Eliade, "Mother earth and the cosmic hierogamies," in Myths, Dreams, and Mysteries, P. Mairet, Trans. New York: Harper and Row, 1960.

[5] F. Cox, "Ovidian metamorphosis in the fiction of A. S. Byatt," in Classics in the Modern World: A Democratic Turn? L. Hardwick and S. Harrison, Eds. Oxford: OUP, 2013.

[6] M. Eliade, "The myths of the modern world," in Myths, Dreams, and Mysteries, P. Mairet, Trans. New York: Harper and Row, 1960.

[7] S. Freud, "Group psychology and the analysis of the ego," in The International Psychological Library, E. Jones, Ed. London: Hogarth, 1949.

[8] J. Lacan, "Some reflections on the ego," International Journal of Psychoanalysis, no. 34, pp. 11-17, 1953.

[9] J. Lacan, "The mirror stage as formative of the / function as revealed in psychoanalytic experience," in Ecrits, Bruce Fink, Trans. New York: Norton, 2006

[10] J. Lacan, "Remarks on Daniel Lagache's presentation," in Ecrits, Bruce Fink, Trans. New York: Norton, 2006

[11] M. Eliade, Rites and Symbols of Initiation, W. R. Trask, Trans. Putnam, Conn.: Spring Publications, 2009.

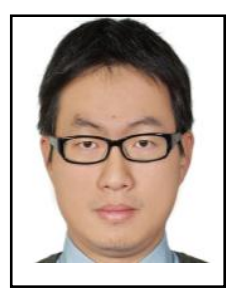

Fred Yifan Lee was born in Taichung, Taiwan, in 1978. He is currently studying in the $\mathrm{PhD}$. program of the Foreign Languages and Literature Department at National Cheng Kung University, Tainan, Taiwan. His major includes English and American literature, psychoanalysis, and cultural studies. He is living in Taichung with his family. 